\title{
Pengelolaan Lahan Berbukit Di Sekitar Pondok Quran Nirwana
}

\author{
Tri Rahayu ${ }^{1}$, Mohamad Ihsan ${ }^{2}$, Umi Nur Solikah ${ }^{3}$, Tri Pamujiasih ${ }^{4}$ \\ Fakultas Pertanian, Universitas Islam Batik Surakarta \\ Email: umi_solikah@yahoo.co.id
}

\begin{abstract}
Abstrak
Penanaman di daerah miring/ berbukit harus diapresiasi untuk mencegah erosi yang lebih parah dan juga meningkatkan fungsi tanaman sebagai penghasil oksigen. Hal ini dapat mengantisipasi terjadinya pemanasan global disebabkan banyaknya CO2 yang tak terserap oleh tanaman (Misan, dkk, 2015). Disamping itu lahan berbukit sebaiknya dikelola dengan benar agar fungsi daya dukungnya lestari, dapat bermanfaat untuk masyarakat secara berkesinambungan.

Tujuan diselenggarakannya kegiatan pengabdian Masyarakat adalah: (1) Membantu penyediaan bahan tanam buah-buahan dan kayu sengon, (2) Memberikan informasi tentang perlunya bahaya lahan miring/ berbukit, (3) Membekali para santri dalam pertanian secara umum (4) Membekali para santri dalam pengelolaan lahan berbukit, (4)Memberikan pengetahuan dan latihan tentang cara-cara mengelola lahan sekitar pondok menjadi sumber pendapatan bagi insan pondok.

Hasil dari kegiatan ini antara lain program ini memberi arahan dalam pengeloaan lahan berbukit untuk pertanian sayuran dan buah serta tanaman lain dan tidak akan berdampak pada kerusakan lingkungan karena erosi. Sehingga lingkungan sekitarnya akan berfungsi dengan baik menjadi lahan yang dapat mendukung pondok secara lestari.
\end{abstract}

Kata Kunci: Pengelolaan, Lahan berbukit, Pondok Quran Nirwana

\section{PENDAHULUAN}

Dewasa ini hampir seluruh lahan kering yang belum digarap dengan baik adalah lahanlahan yang berada di daerah-daerah dengan tofografi agak terjal sampai curam (berbukit-bukit). Akibat pengelolaan lahan yang kurang memperhatikan kaidah pengawetan (konvervasi) tanah dan ditambah bahaya erosi yang berlangsung secara terus menerus, mengakibatkan lahan kritis semakin luas. (Rukmana, 2008)

Aneka tanaman dari tanaman semusim (sayuran) dan tahunan (buah-buahan) sudah ada. Perlu diupayakan lagi jumlah yang lebih banyak dan dengan luasan yang mencukupi. Adapun tujuan dibangunnya pondok adalah menjadikan pondok sebagai pusat kegiatan dalam menghafal dan mempelajari al Quran, mengajak masyarakat untuk berperan serta dan membekali para santri serta masyarakat sekitarnya dengan ilmu agronomi, peternakan dan perkebunan serta pemasaran khususnya hasil dari panen. Disamping itu juga mendukung pemerintah menjadi Desa yang mandiri dengan swasembada pangan dan papan dan pendapatan masyarakat yang meningkat.

Penanaman di daerah miring/ berbukit harus diapresiasi untuk mencegah erosi yang lebih parah dan juga meningkatkan fungsi tanaman sebagai penghasil oksigen dunia satu-satunya. Hal ini dapat mengantisipasi terjadinya pemanasan global disebabkan banyaknya CO2 yang tak terserap oleh tanaman (Misan, dkk, 2015). Disamping itu lahan berbukit sebaiknya dikelola dengan benar agar fungsi daya dukungnya lestari, dapat bermanfaat untuk masyarakat secara berkesinambungan.

Peran serta Fakultas Pertanian Universitas Islam Batik Surakarta (UIBS) dalam implementasi salah satu Tri Darma Perguruan Tinggi adalah melaksanakan pengabdian pada masyarakat. Bentuk pengabdian yang diwujudkan dengan Memberikan ilmu pengetahuan tentang pengelolaan lahan berbukit untuk budidaya tanaman baik semusim maupun tahunan. Selain itu konservasi lingkungan agar dapat berfungsi secara lestari.

Pondok QNIRWANA sudah menghasilkan tanaman buah-buahan dan sayuran yang baru dipasarkan ke daerah dekat-dekat saja. Perlu ditingkatkan kualitas dan kuantitasnya, penanganan 
pasca panennya (pengemasan) dan tataniaganya agar dapat menghasilkan keuntungan yang lebih besar. Dengan keuntungan yang lebih besar dapat mensejahterakan warga pondok dan memperbaiki sarana dan prasarananya. Akhirnya akan terbentuk pondok yang mandiri. Saat ini pemenuhan kebutuhan konsumen untuk komoditas pertanian sebagian besar berasal dari pasar tradisional yang dijual oleh petani dilakukan secara transaksional kepada para pedagang besar maupun pengecer. Agribisnis sayuran yang semakin ketat menuntut pelaku usaha untuk melakukan berbagai upaya strategi bisnis dalam upaya memenangkan persaingan diantaranya dari sisi strategi pemasaran melalui pemasaran relasional (Sadeli, 2017).

2. METODE

Metode pelaksanakan kegiatan pengabdian kepada masyarakat adalah melaksanakan sosialisasi atau penyuluhan tentang pengelolaan lahan berbukit di sekitar pondok Quran Nirwana dan memprakekkan cara menanam tanaman buah, sayuran dan sengon.

\section{HASIL DAN PEMBAHASAN}

Langkah-langkah yang dilakukan dalam kegiatan pengabdian kepada masyarakat "Pengelolaan Lahan Berbukit Di Sekitar Pondok Quran Nirwana" adalah:

\section{(1) Tahap Persiapan Program}

Sebelum dilakukan pengabdian ini dilakukan survey berupa pengamatan dan mencari data pondok. Kemudian dihubungkan dengan Pembibitan Permanen dari DAS Bengawan Solo untuk mendapatkan 1000 bibit buah-buahan dan sengon. Persiapan-persiapan tersebut antara lain: pembuatan proposal, koordinasi dengan kawan satu tim, membuat bahan pelatihan berupa tayangan pengelolan lahan berbukit, budidaya buah dan sayuran, pelatihan pengelolaan pasca panen dan pemasaran hasil.

(2) Tahap Pelaksanaan Program

a. Presentasi Program

Menyajikan materi tentang konsep pengelolaan lahan berbukit yang meliputi konservasi lahan, cara-cara penanaman tanaman sayuran dan buah-buahan, serta pemasaran hasil.

b. Diskusi

Tanya jawab terkait materi yang disajikan dan pengetahuan lain yang terkait kegiatan ini.

c. Praktek Pengelolaan lahan berbukit

1. Melihat lihat lagi area penanaman.

2. Menunjukkan tempat-tempat yang akan ditanami.

3. Menunjukkan cara yang tepat yang berkaitan dengan penanaman

4. Menunjukkan letak/ bidang untuk tanaman sayuran semusim.

5. Praktek pembuatan lubang tanam

6. Praktek pembuatan bedengan untuk pembibitan sayuran.

7. Menunjukkan cara pemeliharaan tanaman secara keseluruhan

8. Menunjukkan cara pempersiapkan pupuk organik yang siap pakai.

d. Kuesioner

Penyebaran kuisioner dimaksudkan untuk mengevaluasi hasil untuk dikembangkan lebih lanjut dalam rangka keberlanjutan untuk pengelolaan lahan berbukit serta konservasi lingkungan.

\section{(3) Tahap Evaluasi Program}

Evaluasi kegiatan mencakup empat aspek target evaluasi:

a. Pemahaman terhadap materi pengelolaan tanah berbukit

b. Pemahaman tentang budidaya sayuran

c. Pemahaman tentang budidaya buah-buahan

d. Pemahaman tentang agribisnis buah-buahan. 


\section{SIMPULAN DAN SARAN}

1. Simpulan

a. Kegiatan pengabdian kepada masyarakat"Pengelolaan Lahan Berbukit Di Sekitar Pondok Quran Nirwana" meliputi tahap persiapan program, tahap pelaksanaan program dan tahap evaluasi program.

b. Manfaat yang diharapkan dari kegiatan ini adalah memberi arahan dalam pengeloaan lahan berbukit untuk pertanian sayuran dan buah serta tanaman lain dan tidak akan berdampak pada kerusakan lingkungan karena erosi. Sehingga lingkungan sekitarnya akan berfungsi dengan baik menjadi lahan yang yang dapat mendukung pondok secara lestari.

2. Saran

a. Perlu adanya tindak lanjut dari pengabdian masyarakat dengan penambahan materi, misalnya tentang pemberantasan hama terpadu.

b. Perlu pelatihan cara pengemasan sehingga buah dan sayuran dapat sampai kepada konsumen tidak mengalami kerusakan .

c. Perlu pelatihan pengolahan hasil buah-buahan agar memperoleh nilai tambah

d. Perlu adanya pelatihan promosi dengan media social agar dikenal banyak orang sehingga penjualan meningkat.

\section{UCAPAN TERIMA KASIH}

Lembaga Penelitian, Pengembangan dan Pengabdian Kepada Masyarakat (LP3M) Universitas Islam Batik Surakarta, Pimpinan Pondok Pesantren QNirwana, Pemuka Masyarakat Dukuh Bangunsari, Kepala Desa Dlepih Kecamatan Tirtomoyo Kabupaten Wonogiri.

\section{DAFTAR PUSTAKA}

Misan, E., N. Nian., F. Widiarti. 2015. Think Green Go Green. Pustaka Jingga. Jakarta. Rukmana, R. 2008. Teknik Pengelolaan Lahan Berbukit dan Kritis. Kanisius. Yogyakarta

Sadeli, Agriani Hermita ,Hesty Nurul Utami, dan Endah Djuwendah. 2017. Strategi Pemasaran Relasional Komoditas Wortel (Studi Kasus di Klaster Agribisnis Kelompok Tani Katata, Pangalengan, Kabupaten Bandung). Sosiohumaniora. Volume 19 No. 1 : 29-36 